\title{
Silagem de grãos úmidos de milho em substituição ao milho seco da ração de frangos de corte criados em dois sistemas
}

\author{
Jane Cristina Gonçalves ${ }^{(1)}$, José Roberto Sartori ${ }^{(1)}$, Antonio Celso Pezzato ${ }^{(1)}$, Ciniro Costa $^{(1)}$, \\ Karina Ludovico de Almeida Martinez ${ }^{(1)}$, Valquíria Cação da Cruz ${ }^{(1)}$, Luciene Aparecida Madeira ${ }^{(1)}$ \\ e Henrique Nunes de Oliveira ${ }^{(1)}$
}

\begin{abstract}
(1)Universidade Estadual Paulista, Fac. de Medicina Veterinária e Zootecnia, Caixa Postal 560, CEP 18618-000 Botucatu, SP. E-mail: janecris@fca.unesp.br, jrsartori@fca.unesp.br, cpezzato@fca.unesp.br, ccosta@fca.unesp.br, karina_ludovico@hotmail.com, valzootec@fca.unesp.br, lucienemadeira@yahoo.com.br, hnunes@fca.unesp.br
\end{abstract}

\begin{abstract}
Resumo - O objetivo do trabalho foi avaliar a inclusão de silagem de grãos úmidos de milho, em substituição ao milho seco, em rações para frangos de corte criados nos sistemas convencional e alternativo. Foram utilizados 720 pintos machos Cobb, com um dia de idade, distribuídos em blocos ao acaso, em esquema fatorial 2x3 (dois sistemas de criação: convencional e alternativo; três níveis de silagem de grãos úmidos, em substituição ao milho seco: $0 \%, 30 \%$ e $60 \%$ ), com quatro repetições cada. Foram obtidas médias de peso, ganho de peso, consumo de ração, conversão alimentar, fator de produção e mortalidade aos 21, 42 e 49 dias de idades. Aos 49 dias, foram abatidas 28 aves, por tratamento, para determinação do rendimento de carcaça, cortes e gordura abdominal. A inclusão de até $60 \%$ de silagem de grãos úmidos, em substituição ao milho seco, reduziu o custo da ração, sem alterar o desempenho das aves aos 21, 42 e 49 dias, nem o rendimento de carcaça aos 49 dias. No sistema de criação alternativo, independentemente do nível de inclusão de silagem de grãos úmidos, o desempenho dos frangos foi inferior, porém o retorno econômico foi maior.
\end{abstract}

Termos para indexação: aves, alimentos alternativos, desempenho, gordura abdominal, rendimento de carcaça.

\section{High moisture corn grains silage in substitution of diet dry corn to broilers bred in two systems}

\begin{abstract}
The aim of this work was to evaluate the inclusion of high moisture corn grains silage, in substitution of dry corn, in diets of broilers bred in conventional and alternative systems. One-day old male Cobb chicks (720) were distributed in randomized blocks, according to a 2x3 factorial consisting of two systems (conventional and alternative), and three levels of silage ( $0 \%, 30 \%$ and $60 \%)$, with four replications per treatment. Means of weight, weight gain, ration consumption, feed conversion, production factor and mortality were obtained in 21, 42 and 49 days old broilers. In the final of the experiment 28 chickens per treatment were used to determine carcass yield, cuts and abdominal fat. The inclusion in diet until 60\% of humid grain corn silage, in substitution of dry corn, decreased the ration cost, without affecting performance (in 21, 42 and 49 days old) and carcass yield of broilers (49 days). In alternative breeding system, independently of inclusion level of high moisture corn grains silage, performance was lower, however the economic return was higher.
\end{abstract}

Index terms: poultry, alternative feed, performance, abdominal fat, carcass yield.

\section{Introdução}

Tem se observado uma preocupação cada vez maior dos consumidores com a qualidade dos produtos, exigindo alimentos saudáveis e ausência de resíduos. As empresas avícolas buscam acompanhar esta tendência, e para isso voltam-se para a produção do frango alternativo, que consiste na exploração intensiva de aves de corte alojadas em menor densidade e alimentadas com dietas isentas de antibióticos, anticoccidianos, promoto- res de crescimento, quimioterápicos e ingredientes de origem animal, além de uma série de outros requisitos e normas, aprovadas e oficializadas no âmbito da Associação de Avicultura Alternativa (Demattê Filho \& Mendes, 2001).

Entre os produtos que são utilizados em dietas de frangos de corte e poedeiras, em substituição aos promotores de crescimento, podem ser citados os ácidos orgânicos, cuja inclusão na ração potencializa os ganhos nutricionais, o desempenho (Garcia et al., 1995), o ren- 
dimento de carcaça (Samanta \& Biswas, 1995), bem como inibe a proliferação de enterobactérias indesejáveis no trato digestório das aves (Waldroup et al., 1995). Além disso, os ácidos orgânicos evitam o desenvolvimento de fungos, durante a estocagem, em grãos de alta umidade e em rações. As maiores limitações para a utilização de ácidos orgânicos nas rações são o seu elevado custo e a dificuldade operacional, pois tais ácidos são extremamente irritantes para a pele, de difícil manuseio e corrosivos para os equipamentos (Vale, 1998).

A silagem de grãos úmidos de milho pode ser definida como o produto da conservação, em meio anaeróbio, de grãos de milho logo após sua maturação fisiológica, que consiste no término da translocação de nutrientes da planta para os grãos, ocasião em que apresentam teores máximos de amido, proteínas e óleos, além de umidade elevada, ao redor de $28 \%$, com amplitude de $25 \%$ a $30 \%$ (Costa et al., 1999). Pelo fato da silagem de grãos úmidos possuir ácidos orgânicos, produzidos por meio da fermentação microbiana anaeróbia, com redução do pH e conservação da silagem, esta pode ser considerada uma fonte alternativa de inclusão desses ácidos nas rações de aves e suínos.

Há evidências de que a fermentação anaeróbia, ocorrida nos processos de ensilagem, propicia um produto com maior disponibilidade de energia para os animais do que o milho comum (Lima, 2001). Segundo Sartori et al. (2002), a silagem de grãos úmidos de milho, em substituição total ao milho seco, não altera o desempenho, o rendimento de carcaça e o peso de órgãos de frangos de corte criados até 21 dias de idade.

Este trabalho teve por objetivos estudar o efeito da inclusão de silagem de grãos úmidos de milho, em substituição ao milho seco, na ração de frangos de corte criados nos sistemas convencional e alternativo, sobre o desempenho, o rendimento de carcaça, os cortes e a gordura abdominal, e realizar a análise econômica dos sistemas de criação.

\section{Material e Métodos}

O experimento foi realizado no período de 18 de outubro a 5 de dezembro de 2001, na Faculdade de Medicina Veterinária e Zootecnia, Unesp, Campus de Botucatu. Foram utilizados 720 pintos de corte, machos, da linhagem Cobb, com um dia de idade, vacinados no incubatório contra as doenças de Gumboro, Marek e Bouba aviária. As aves criadas no sistema alternativo foram vacinadas contra coccidiose (Coccivac), via as- persão, no incubatório. Quanto à doença de Gumboro, todas as aves foram vacinadas aos oito e 18 dias de idade, com a vacina viva liofilizada Gumboro 228E - Nobilis, via água de beber, conforme recomendação do fabricante.

Os seis tratamentos, cada um com 30 aves e quatro repetições, consistiram de: ração com grãos de milho seco, sem inclusão de silagem de grãos úmidos de milho, mais promotor de crescimento e coccidicida (convencional); ração convencional com inclusão de 30\% de silagem de grãos úmidos de milho, em substituição aos grãos secos; ração convencional com inclusão de $60 \%$ de silagem de grãos úmidos de milho, em substituição aos grãos secos; ração com grãos de milho seco, sem inclusão de silagem de grãos úmidos de milho e sem promotor de crescimento e coccidicida (alternativa); ração alternativa com inclusão de 30\% de silagem de grãos úmidos de milho, em substituição aos grãos secos; e ração alternativa com inclusão de $60 \%$ de silagem de grãos úmidos de milho, em substituição aos grãos secos.

Para o preparo da silagem de grãos úmidos de milho utilizou-se o híbrido Co34, de textura semidura, com 26,16\% de umidade, plantado especialmente para esta finalidade. Após ser colhido mecanicamente, foi devidamente moído (peneira $4 \mathrm{~mm}$ ) e compactado em tambores de plástico de $220 \mathrm{~kg}$, segundo método descrito por Costa et al. (1999) e Nummer Filho (2001). O mesmo híbrido de milho foi utilizado no processamento das rações com grãos secos (12\% de umidade), moídos na mesma peneira utilizada para processar o milho úmido.

A abertura dos tambores com silagem de grãos úmidos foi feita após seis meses de fermentação, tendo-se desprezado uma camada de aproximadamente $10 \mathrm{~cm}$ de espessura, em cada tambor, em função da eventual proliferação de microrganismos na superfície.

As rações foram formuladas segundo recomendações de Rostagno et al. (2000), considerando-se as fases de criação inicial, crescimento e final (Tabela 1).

O fornecimento de água e ração foi ad libitum. Nos tratamentos que continham $30 \%$ e $60 \%$ de silagem de grãos úmidos de milho, em substituição ao milho seco, a silagem foi adicionada e misturada diariamente, tendo-se adotado o fator de correção de 1,192, obtido por meio da relação entre a matéria seca do milho seco (88\%) e a matéria seca da silagem $(73,84 \%)$, a fim de manter a mesma quantidade de matéria seca em todas as dietas. As sobras das rações com silagem de grãos úmidos foram registradas diariamente e desprezadas. 
As sobras das rações que não continham silagem foram pesadas e anotadas semanalmente.

A temperatura e a ventilação foram controladas manualmente, manejando-se as cortinas laterais do galpão. $\mathrm{O}$ fornecimento de luz às aves foi constante, e as campânulas foram retiradas no sétimo dia de idade.

Nos períodos acumulados de 1-21, 1-42 e 1- 49 dias de idade, foram obtidas as seguintes variáveis de desempenho: peso corporal (peso das aves de cada boxe no alojamento, aos 21, 42 e 49 dias); ganho de peso (calculado pela diferença entre peso ao final de cada período e peso inicial no alojamento); ganho de peso diário (calculado pela diferença entre peso ao final de cada período e peso inicial no alojamento, dividido pelo número de dias no período); consumo total de ração (obtido pela diferença entre total de ração fornecida e sobras colhidas no final de cada período, baseado no número médio de aves); conversão alimentar (calculada pela razão entre total de ração consumida e ganho de peso, corrigida pelo peso das aves mortas); fator de produção (calculado pela razão entre ganho de peso médio diário das aves, multiplicado pela viabilidade, divido pela conversão alimentar, tudo isso multiplicado por 100) e mortalidade (anotada diariamente e expressa em porcentual, pela relação entre número de aves mortas no período e número inicial de aves).

O rendimento de carcaça, cortes e gordura abdominal foram obtidos ao final do período de criação e as aves foram submetidas a 8 horas de jejum e pesadas antes

Tabela 1. Composição porcentual e nutricional calculada, das rações para as fases de criação inicial (até 21 dias), crescimento (22- 42 dias) e final (43-49 dias), de frangos de corte criados nos sistemas convencional (CO) e alternativo (AL).

\begin{tabular}{|c|c|c|c|c|c|}
\hline \multirow[t]{2}{*}{ Ingrediente (\%) } & \multicolumn{2}{|c|}{ Inicial } & \multicolumn{2}{|c|}{ Crescimento } & \multirow{2}{*}{$\begin{array}{r}\text { Final } \\
\mathrm{CO} / \mathrm{AL}\end{array}$} \\
\hline & $\mathrm{CO}$ & $\mathrm{AL}$ & $\mathrm{CO}$ & $\mathrm{AL}$ & \\
\hline Milho & 58,383 & 58,359 & 63,779 & 63,783 & 66,203 \\
\hline Farelo de soja & 35,440 & 35,500 & 29,790 & 29,830 & 26,660 \\
\hline Óleo de soja & 2,400 & 2,400 & 2,944 & 2,944 & 4,000 \\
\hline Sal comum & 0,350 & 0,350 & 0,350 & 0,350 & 0,350 \\
\hline Suplemento vitamínico ${ }^{(1)}$ & 0,080 & 0,080 & 0,050 & 0,050 & 0,050 \\
\hline Suplemento mineral ${ }^{(2)}$ & 0,050 & 0,050 & 0,050 & 0,050 & 0,050 \\
\hline Calcário calcítico & 1,000 & 1,000 & 0,950 & 0,940 & 0,890 \\
\hline Fosfato bicálcico & 1,820 & 1,820 & 1,620 & 1,620 & 1,430 \\
\hline DL-metionina & 0,230 & 0,230 & 0,160 & 0,160 & 0,160 \\
\hline L-lisina & 0,170 & 0,170 & 0,220 & 0,220 & 0,170 \\
\hline Promotor de crescimento ${ }^{(3)}$ & 0,008 & - & 0,006 & - & - \\
\hline Anticoccidiano $^{(4)}$ & 0,028 & - & 0,028 & - & - \\
\hline Cloreto de colina $(70 \%)$ & 0,041 & 0,041 & 0,053 & 0,053 & 0,037 \\
\hline Total & 100,000 & 100,000 & 100,000 & 100,000 & 100,000 \\
\hline \multicolumn{6}{|l|}{ Composicão calculada } \\
\hline Energia metabolizável $\left(\mathrm{kcal} \mathrm{kg}^{-1}\right)$ & 3.000 & 3.000 & 3.100 & 3.101 & 3.202 \\
\hline Proteína bruta $(\%)$ & 21,41 & 21,44 & 19,30 & 19,32 & 18,04 \\
\hline Cálcio $(\%)$ & 0,97 & 0,97 & 0,88 & 0,88 & 0,80 \\
\hline Fósforo $(\%)$ & 0,45 & 0,45 & 0,41 & 0,41 & 0,37 \\
\hline Metionina (\%) & 0,56 & 0,56 & 0,46 & 0,46 & 0,44 \\
\hline Aminoácidos sulfurados (\%) & 0,89 & 0,89 & 0,77 & 0,77 & 0,74 \\
\hline Lisina $(\%)$ & 1,27 & 1,27 & 1,16 & 1,16 & 1,04 \\
\hline Potássio (\%) & 0,83 & 0,83 & 0,74 & 0,74 & 0,69 \\
\hline Sódio $(\%)$ & 0,18 & 0,18 & 0,18 & 0,18 & 0,18 \\
\hline Cloro (\%) & 0,24 & 0,24 & 0,24 & 0,24 & 0,24 \\
\hline Ácido linoléico (\%) & 2,67 & 2,67 & 3,02 & 3,02 & 3,62 \\
\hline
\end{tabular}

(1)Suplemento vitamínico (por quilograma de produto) na fase inicial: vit. A, 10.000.000 UI; vit. D, 2.000.000 UI; vit. E, 12.500 mg; ác. nicotínico, $30.000 \mathrm{mg}$; vit. K, $2.500 \mathrm{mg}$; ác. pantotênico, $12.500 \mathrm{mg}$; ác. fólico, $1.000 \mathrm{mg}$; vit. $\mathrm{B}_{1}$, $2.400 \mathrm{mg}$; vit. $\mathrm{B}_{2}$, $6.000 \mathrm{mg}$; vit. $\mathrm{B}_{6}$, $3.200 \mathrm{mg}$; vit. $\mathrm{B}_{12}, 12.000 \mu \mathrm{g}$; antioxidante, $15 \mathrm{~g}$; selênio, $200 \mathrm{mg}$; veículo q.s.p., 1.000 g; suplemento na fase de crescimento: vit. A, 14.000 .000 UI; vit. D, 3.200.000 UI; vit. E, 28.000.000 UI; ác. nicotínico, 60.000 mg; vit. K, 3.600 mg; ác. pantotênico, 20.000 g; ác. fólico, 1.200 mg; vit. B 1 , $3.000 \mathrm{mg}$; vit. $\mathrm{B}_{2}, 10.000 \mathrm{mg}$; vit. $\mathrm{B}_{6}, 4.800 \mathrm{mg}$; vit. $\mathrm{B}_{12}, 20.000 \mu$ g; veículo q.s.p., $1.000 \mathrm{~g}$; suplemento na fase final: vit. A, $5.000 .000 \mathrm{UI}$; vit. D, 1.400.000 UI; vit. E, 14.000.000 UI; ác. nicotínico, 36.000 mg; vit. K, 1.400 mg; ác. pantotênico, 14.000 mg; ác. fólico, 400 mg; vit. B , $1.000 \mathrm{mg}$; vit. $\mathrm{B}_{2}$, $5.000 \mathrm{mg}$; vit. $\mathrm{B}_{6}, 1.000 \mathrm{mg}$; vit. $\mathrm{B}_{12}$, $12.000 \mu$ g; vit. H, $80.000 \mu$ g; veículo q.s.p., 1.000 g. (2)Suplemento mineral (por quilograma de produto): cobre, $20.000 \mathrm{mg}$; ferro, $100.000 \mathrm{mg}$; iodo, $2.000 \mathrm{mg}$; manganês, $140.000 \mathrm{mg}$; selênio, 600 mg; zinco, 120.000 mg; veículo q.s.p., 1.000 g. ${ }^{(3)}$ Surmax (10\% de avilamicina). ${ }^{(4)}$ Coban (monensina). 
do abate. No abate foi feita a sangria, após as aves terem sido aturdidas por choque elétrico. Em seguida, foi realizada a evisceração e resfriamento em câmara fria, sem passar pelo chiller, e então as carcaças foram pesadas, cortadas e desossadas por procedimento industrial. Em relação ao peso vivo, obtido na plataforma imediatamente antes do abate, foram anotados os seguintes dados de rendimento: rendimento de carcaça (sem pés, cabeça, pescoço e vísceras comestíveis), peito, carne de peito, ossos de peito, pele de peito, pernas (comumente denominadas coxa e sobrecoxa), carne de pernas, ossos de pernas, pele de pernas, dorso, asas, pés, cabeça+pescoço e gordura abdominal (constituída pela gordura perianal e a gordura que envolve a moela e o proventrículo).

No intuito de evitar a contaminação entre boxes (tratamentos sem promotor de crescimento e coccidicida $\mathrm{x}$ com promotor de crescimento e coccidicida) foram utilizadas botas plásticas, tendo sido uma para os boxes vacinados e outra para os não vacinados. Além disto, foram colocadas bandejas com cal na porta de entrada dos boxes que alojavam pintos vacinados, para funcionar como um pedilúvio.

Na análise de ácidos orgânicos, amostras de silagem de grãos úmidos foram colhidas dos tambores e encaminhadas ao Laboratório de Bromatologia, da Faculdade de Zootecnia e Engenharia de Alimentos, USP, Campus de Pirassununga. As amostras foram processadas de acordo com o Supelco Bulletin (1998), para então serem submetidas à determinação do ácido lático, por cromatografia líquida (Danner et al., 2000; MolnárPerl, 2000), e dos ácidos acético, butírico e propiônico, por cromatografia gasosa (Wilson, 1971). Segundo esse método, foi determinada também a porcentagem de etanol. Amostras de ração, milho seco e silagem de grãos úmidos foram colhidas para análise de $\mathrm{pH}$.

A avaliação econômica da produção foi realizada, utilizando-se como parâmetros os valores dos custos reais de pintos, rações, vacinas, medicamentos, cama e uma porcentagem fixa para todos os tratamentos, representando os demais custos, conforme a planilha utilizada pela Associação Paulista de Avicultura, para apuração do custo do quilograma de frango vivo. No cálculo da receita, foram utilizados os preços de venda do quilograma de frango vivo praticados nos mercados convencional e alternativo.

Para a análise estatística dos dados de desempenho e mortalidade, foi adotado um delineamento em parce- las subdivididas em blocos ao acaso, considerando-se os tratamentos principais no esquema fatorial $2 \times 3$, cujo fatores consistiram nos sistemas de criação convencional e alternativo e na inclusão de $0 \%, 30 \%$ e $60 \%$ de silagem de grãos úmidos de milho, em substituição aos grãos secos, com quatro repetições de 30 aves cada, num total de 120 aves por tratamento. Os tratamentos secundários foram as idades de observação 21, 42 e 49 dias. Para a análise de rendimento de carcaça foram utilizadas 28 aves de cada tratamento.

A análise estatística dos dados de desempenho, mortalidade, rendimento de carcaça, cortes e gordura abdominal foi feita pelo método de análise de variância (ANOVA), com o auxílio do procedimento GLM do programa SAS Institute (1996) e, para verificar diferenças significativas entre as médias dos tratamentos, foi utilizado o teste de Student-Newman-Keuls (SNK) a 5\% de probabilidade.

\section{Resultados e Discussão}

Pela análise de ácidos orgânicos, das amostras de silagem de grãos úmidos de milho, foi possível expressar os valores médios porcentuais, em $100 \%$ de matéria seca, de etanol, de ácido lático e de ácido acético, que foram: $0,4380 \%, 3,3130 \%$ e $0,0362 \%$, respectivamente. Não foram detectados os ácidos propiônico e butírico. Esses valores estão entre aqueles considerados como ideais para assegurar boa estabilidade à silagem de grãos úmidos, após abertura do silo, onde os teores de ácido lático devem estar entre $1 \%$ e $3 \%$, acético menor que $0,1 \%$, propiônico entre zero e $1 \%$ e butírico menor que 0,1\% (Mahanna, 1994). A adição de ácidos orgânicos em dietas diminui o $\mathrm{pH}$ gástrico, o que acarreta diminuição do crescimento bacteriano (Maiorka, 2001). Além disso, sabe-se que alguns ácidos como o propiônico, o fórmico, o sórbico e o lático exercem efeito bactericida, quando estão em sua forma não dissociada, e penetram, deste modo, nas células (Jorge Neto \& Dari, 2000).

$\mathrm{Na}$ análise de $\mathrm{pH}$ foram encontrados valores de 6,3 e 4, para o milho seco e silagem de grãos úmidos de milho, respectivamente. A inclusão de silagem de grãos úmidos de milho reduziu o $\mathrm{pH}$ das rações, as quais apresentaram valores de 6,6, 6,1 e 5,6 para rações com 0\%, $30 \%$ e $60 \%$ de silagem de grãos úmidos de milho, em substituição ao milho seco, respectivamente. Segundo Lopes (2000), o menor pH das rações está diretamente relacionado com a maior digestibilidade delas, o que pôde 
explicar o melhor desempenho e menor incidência de diarréia em leitões, na fase inicial, alimentados com ração com silagem de grãos úmidos de milho.

Não houve interação entre sistemas de criação das aves e níveis de substituição do milho seco pela silagem de grãos úmidos de milho, em nenhuma das fases de criação (1-21, 1-42 e 1-49 dias), para os dados de desempenho e mortalidade (Tabela 2), com exceção do ganho de peso médio diário, nas fases de 1-42 e 1-49 dias (Tabela 3).

As aves criadas no sistema convencional apresentaram maiores médias de peso final, ganho de peso, ganho de peso diário e melhor conversão alimentar $(\mathrm{p}<0,05)$, nas três idades avaliadas, quando comparadas às do sistema alternativo (Tabela 2). Esses resultados estão em conformidade com a literatura e boletins técnicos da indústria avícola, de países que proibiram o uso dos promotores de crescimento, tendo-se observado que quanto mais adversas forem as condições às quais as aves estiverem submetidas, mais acentuadas serão as diferenças nos resultados (Butolo, 1999). Não foram observados efeitos da inclusão de silagem de grãos úmi- dos para nenhuma das variáveis de desempenho estudadas, nas três fases de criação (Tabela 2). Martins et al. (2000) observaram efeito depressor no peso final de frangos, aos 42 dias, ao trabalharem com 100\% de inclusão de silagem de grãos úmidos de milho. Tal fato é explicado, em parte, pela limitação física do trato digestório, em conseqüência do elevado teor de umidade das rações. Entretanto, Sartori et al. (2002) relataram que a silagem de grãos úmidos de milho pode substituir totalmente o milho seco das dietas de frangos de corte criados até 21 dias de idade.

Nas fases de 1-42 e 1-49 dias (Tabela 3), os frangos criados no sistema convencional tiveram maiores $(p<0,05)$ médias de ganho de peso diário, ao receberem ração com até $30 \%$ de inclusão de silagem de grãos úmidos, quando comparados às aves criadas no sistema alternativo. Nas aves alimentadas com $60 \%$ de inclusão de silagem de grãos úmidos, tal efeito não foi observado, o que está em conformidade com os dados obtidos por Carrijo et al. (2000), que trabalharam com 100\% de inclusão em dietas convencionais com promotores de crescimento. Isto sugere certo antagonismo entre a

Tabela 2. Valores médios de peso final (PF), ganho de peso (GP), ganho de peso diário (GPD), consumo de ração (CR), conversão alimentar (CA), mortalidade (MORT) e fator de produção (FP) de frangos de corte, nas fases de criação de 1-21, 1-42 e 1-49 dias, conforme a inclusão de silagem de grãos úmidos de milho e os sistemas de criação convencional (CO) e alternativo (AL).

\begin{tabular}{|c|c|c|c|c|c|c|c|}
\hline \multirow{2}{*}{$\begin{array}{l}\text { Fase de } \\
\text { criação (dias) }\end{array}$} & \multirow[t]{2}{*}{ Parâmetro } & \multicolumn{3}{|c|}{ Inclusão de silagem de grãos úmidos } & \multicolumn{2}{|c|}{ Sistemas de criação $^{(1)}$} & \multirow[t]{2}{*}{ CV $(\%)$} \\
\hline & & 0 & 30 & 60 & $\mathrm{CO}$ & $\mathrm{AL}$ & \\
\hline \multirow[t]{6}{*}{$1-21$} & $\mathrm{PF}(\mathrm{g})$ & 891 & 900 & 887 & $900 \mathrm{a}$ & $885 \mathrm{~b}$ & 1,53 \\
\hline & GP (g) & 844 & 853 & 840 & $853 a$ & $838 \mathrm{~b}$ & 1,61 \\
\hline & GPD $(g)$ & 40 & 41 & 40 & $41 \mathrm{a}$ & $40 \mathrm{~b}$ & 1,61 \\
\hline & $\mathrm{CR}^{(2)}(\mathrm{g})$ & 1.156 & 1.152 & 1.147 & 1.149 & 1.153 & 1,85 \\
\hline & $\mathrm{CA}^{(2)}$ & 1,374 & 1,359 & 1,368 & $1,357 \mathrm{~b}$ & $1,377 \mathrm{a}$ & 0,85 \\
\hline & $\operatorname{MORT}^{(3)}(\%)$ & 2,08 & 2,92 & 0,42 & 2,78 & 0,83 & 49,77 \\
\hline \multirow[t]{7}{*}{$1-42$} & $\mathrm{PF}(\mathrm{g})$ & 2.563 & 2.566 & 2.519 & $2.603 a$ & $2.498 b$ & 2,40 \\
\hline & GP (g) & 2.516 & 2.518 & 2.472 & $2.556 \mathrm{a}$ & $2.451 \mathrm{~b}$ & 2,45 \\
\hline & GPD (g) & $60^{(5)}$ & 60 & 59 & $61^{(5)}$ & 58 & 2,45 \\
\hline & $\mathrm{CR}^{(2)}(\mathrm{g})$ & 4.402 & 4.406 & 4.327 & 4.390 & 4.366 & 2,48 \\
\hline & $\mathrm{CA}^{(2)}$ & 1,765 & 1,760 & 1,764 & $1,733 b$ & $1,790 \mathrm{a}$ & 1,59 \\
\hline & $\operatorname{MORT}^{(3)}(\%)$ & 5,24 & 5,83 & 5,00 & 6,36 & 4,44 & 51,54 \\
\hline & $\mathrm{FP}^{(4)}$ & 320,16 & 320,98 & 317,64 & 328,81 & 311,68 & 5,99 \\
\hline \multirow[t]{7}{*}{$1-49$} & $\mathrm{PF}(\mathrm{g})$ & 3.081 & 3.085 & 3.011 & $3.114 \mathrm{a}$ & $3.007 \mathrm{~b}$ & 2,57 \\
\hline & GP $(g)$ & 3.034 & 3.037 & 2.964 & $3.067 \mathrm{a}$ & $2.959 b$ & 2,61 \\
\hline & GPD (g) & $62^{(5)}$ & 62 & 60 & $63^{(5)}$ & 60 & 2,61 \\
\hline & $\mathrm{CR}^{(2)}(\mathrm{g})$ & 5.570 & 5.629 & 5.508 & 5.602 & 5.539 & 2,18 \\
\hline & $\mathrm{CA}^{(2)}$ & 1,854 & 1,873 & 1,872 & $1,844 \mathrm{~b}$ & $1,888 \mathrm{a}$ & 2,12 \\
\hline & $\operatorname{MORT}^{(3)}(\%)$ & 5,71 & 8,33 & 5,00 & 6,97 & 5,83 & 51,16 \\
\hline & $\mathrm{FP}^{(4)}$ & 314,26 & 304,03 & 307,29 & 315,59 & 301,58 & 7,28 \\
\hline
\end{tabular}

(1)Médias na linha, seguidas de letras minúsculas diferentes, diferem significativamente entre si a 5\% de probabilidade, pelo teste F. (2)Valores corrigidos com base na matéria seca do milho seco $(88 \%)$. ${ }^{(3)}$ Mortalidade corrigida para $(\mathrm{x}+0,5)^{1 / 2}$. ${ }^{(4)}$ Fator de produção $=[(\mathrm{GPD} \mathrm{x}$ Viabilidade $) / \mathrm{CA}] \mathrm{x} 100$. (5)Interação entre silagem de grãos úmidos de milho e sistema de criação. 
utilização de promotor de crescimento e silagem de grãos úmidos de milho, em níveis muito elevados na ração. Andrade et al. (2002) obtiveram melhora no desempenho de frangos de corte, que receberam ração sem nenhum aditivo, e utilizaram dietas com 50\% de silagem de grãos úmidos de milho, em substituição ao milho seco.

Em relação ao rendimento de carcaça (Tabela 4), não houve interação entre sistemas de criação e níveis de substituição do milho seco pela silagem de grãos úmidos de milho, para nenhuma das características avaliadas, bem como efeito da inclusão de silagem de grãos úmidos de milho. Gonçalves et al. (2002) relataram que a silagem de grãos úmidos de milho pode substituir o milho seco em rações de frangos de corte, sem comprometer o rendimento de carcaça e os cortes, apesar de terem verificado aumento na deposição de gordura na carcaça.

Tabela 3. Valores médios (g) de ganho de peso diário de frangos de corte, nas fases de criação de 1-42 e de 1-49 dias, conforme a inclusão de silagem de grãos úmidos de milho e os sistemas de criação convencional (CO) e alternativo (AL).

\begin{tabular}{lcccccc}
\hline Fase de & & Sistema de & \multicolumn{2}{l}{ Inclusão de silagem de grãos úmidos (\%) } & Média & CV (\%) \\
\cline { 3 - 5 } criação (dias) & criação & 0 & 30 & 60 & & \\
\hline $1-42$ & $\mathrm{CO}$ & $61 \mathrm{aA}$ & $61 \mathrm{aA}$ & $60 \mathrm{aA}$ & 61 & 2,45 \\
& $\mathrm{AL}$ & $59 \mathrm{aB}$ & $59 \mathrm{aB}$ & $58 \mathrm{aA}$ & 58 & \\
\hline Média & & 60 & 60 & 59 & & \\
\hline $1-49$ & $\mathrm{CO}$ & $64 \mathrm{aA}$ & $63 \mathrm{aA}$ & $61 \mathrm{aA}$ & 63 & 2,61 \\
& $\mathrm{AL}$ & $60 \mathrm{aB}$ & $61 \mathrm{aB}$ & $60 \mathrm{aA}$ & 60 & \\
\hline Média & & 62 & 62 & 60 & & \\
\hline
\end{tabular}

(1)Médias seguidas de letras iguais, minúsculas nas linhas e maiúsculas nas colunas, não diferem significativamente entre si a 5\% de probabilidade, pelo teste de Student-Newman-Keuls e F, respectivamente.
As aves criadas no sistema alternativo tiveram maiores rendimentos $(p<0,05)$ de pés e de cabeça+pescoço. Para as outras variáveis de rendimento, não houve diferença entre os sistemas de criação (Tabela 4).

Na avaliação econômica da produção, foi observado que a inclusão de silagem de grãos úmidos de milho diminuiu o custo por quilograma das rações, para ambos os sistemas de criação em 9,43\% no sistema convencional (de US\$ 0,1623 kg-1 para US\$ 0,1470 $\mathrm{kg}^{-1}$ ), e 9,55\% no sistema alternativo com $30 \%$ de substituição (de US\$ 0,1602 para US\$ 0,1449 $\mathrm{kg}^{-1}$ ); $18,30 \%$ no sistema convencional (de US\$ 0,1623 $\mathrm{kg}^{-1}$ para US\$ $0,1326 \mathrm{~kg}^{-1}$ ), e $18,41 \%$ no sistema alternativo com $60 \%$ de substituição (de US\$ 0,1602 para US\$ $0,1307 \mathrm{~kg}^{-1}$ ). Houve redução no custo total de produção de $7,79 \%$ e de $11,98 \%$ no sistema de criação convencional, e de $8,38 \%$ e $15,44 \%$ no sistema de criação alternativo, quando se incluíram 30\% e 60\% de silagem de grãos úmidos de milho, em substituição aos grãos de milho secos, respectivamente (Tabela 5).

Essa redução de custo das rações pode ser explicada pelo menor custo dos grãos de milho úmido, em comparação aos grãos secos, por terem sido eliminadas as etapas de limpeza e secagem. Assim, o custo total de produção de silagem de grãos úmidos é 4\% menor que o custo do milho seco no armazém (Beltrame Filho, 2001, citado por Berto et al., 2001).

A receita, por ave, foi maior no sistema de criação alternativo, quando comparada à do sistema convencional, o que resulta em lucro maior, por ave, de US\$1,070, US\$ 1,057 e US\$ 1,066, para aves que receberam $0 \%$,

Tabela 4. Valores médios de rendimento de carcaça e cortes de frangos, abatidos aos 49 dias, conforme a inclusão de silagem de grãos úmidos de milho e os sistemas de criação convencional (CO) e alternativo (AL).

\begin{tabular}{|c|c|c|c|c|c|c|}
\hline \multirow[t]{2}{*}{ Parâmetro $^{(1)}$} & \multicolumn{3}{|c|}{ Inclusão de silagem de grãos úmidos (\%) } & \multicolumn{2}{|c|}{ Sistemas de criação $^{(2)}$} & \multirow[t]{2}{*}{$\mathrm{CV}(\%)$} \\
\hline & 0 & 30 & 60 & $\mathrm{CO}$ & $\mathrm{AL}$ & \\
\hline Peso vivo $(\mathrm{g})$ & 2.975 & 3.016 & 2.958 & 3.012 & 2.956 & 7,34 \\
\hline Carcaça eviscerada (\%) & 73,85 & 73,60 & 73,74 & 73,95 & 73,51 & 1,90 \\
\hline Cabeça e pescoço $(\%)$ & 5,46 & 5,63 & 5,60 & $5,41 b$ & $5,71 \mathrm{a}$ & 10,79 \\
\hline Pés $(\%)$ & 4,04 & 4,12 & 4,15 & $4,06 b$ & $4,15 \mathrm{a}$ & 6,23 \\
\hline Gordura abdominal (\%) & 1,88 & 1,94 & 1,91 & 2,01 & 1,82 & 31,58 \\
\hline Asas (\%) & 8,03 & 8,00 & 8,07 & 8,05 & 8,02 & 3,71 \\
\hline Peito $(\%)$ & 24,07 & 23,94 & 24,10 & 24,02 & 24,05 & 11,53 \\
\hline Pernas $(\%)$ & 24,15 & 24,04 & 24,06 & 24,17 & 23,99 & 3,97 \\
\hline Dorso (\%) & 17,18 & 17,30 & 17,08 & 17,30 & 17,09 & 5,65 \\
\hline Ossos de peito $(\%)$ & 3,63 & 3,55 & 3,64 & 3,58 & 3,62 & 10,05 \\
\hline Pele de peito $(\%)$ & 1,73 & 1,71 & 1,82 & 1,72 & 1,79 & 16,19 \\
\hline Carne de peito $(\%)$ & 18,37 & 18,35 & 18,34 & 18,43 & 18,28 & 7,03 \\
\hline Ossos de pernas $(\%)$ & 4,91 & 4,88 & 5,00 & 4,98 & 4,89 & 9,18 \\
\hline Pele de pernas $(\%)$ & 2,56 & 2,55 & 2,58 & 2,59 & 2,54 & 11,03 \\
\hline Carne de pernas $(\%)$ & 16,59 & 16,50 & 16,39 & 16,50 & 16,48 & 6,08 \\
\hline
\end{tabular}

${ }^{(1)}$ Rendimento de carcaça e cortes $(\%)=$ (peso da carcaça ou dos cortes/peso vivo) x 100. (2)Médias na linha seguidas de letras diferentes diferem significativamente entre si a $5 \%$ de probabilidade, pelo teste $\mathrm{F}$. 
Tabela 5. Análise econômica, conforme os sistemas de criação convencional (CO) e alternativo (AL), e a inclusão de 0\%, 30\% e $60 \%$ de silagem de grãos úmidos de milho na ração de frangos de corte ${ }^{(1)}$.

\begin{tabular}{|c|c|c|c|c|c|c|}
\hline \multirow[t]{2}{*}{ Parâmetro } & \multicolumn{3}{|c|}{ Convencional } & \multicolumn{3}{|c|}{ Alternativo } \\
\hline & $0 \%$ & $30 \%$ & $60 \%$ & $0 \%$ & $30 \%$ & $60 \%$ \\
\hline Total de aves & 100 & 100 & 100 & 100 & 100 & 100 \\
\hline Mortalidade (\%) & 8,89 & 9,17 & 3,33 & 3,33 & 7,50 & 6,67 \\
\hline Peso vivo final (kg) & 290,19 & 285,93 & 292,60 & 290,36 & 279,49 & 279,54 \\
\hline Consumo de ração (kg) & 516,94 & 512,11 & 532,81 & 530,98 & 519,84 & 513,69 \\
\hline Custo da ração ${ }^{(2)}$ (US\$) & 83,90 & 75,28 & 70,65 & 85,06 & 75,32 & 67,14 \\
\hline Custo dos pintos (US\$) & 14,65 & 14,65 & 14,65 & 18,96 & 18,96 & 18,96 \\
\hline Outros custos $^{(3)}$ (US\$) & 12,07 & 12,07 & 12,07 & 12,07 & 12,07 & 12,07 \\
\hline Custo total (US\$) & 110,62 & 102,00 & 97,37 & 116,09 & 106,36 & 98,17 \\
\hline Preço/kg vivo ${ }^{(4)}(\mathrm{US} \$)$ & 0,384 & 0,384 & 0,384 & 0,759 & 0,759 & 0,759 \\
\hline Receita total (US\$) & 111,32 & 109,68 & 112,24 & 220,27 & 212,02 & 212,06 \\
\hline Lucro total (US\$) & 0,70 & 7,68 & 14,87 & 104,18 & 105,67 & 113,89 \\
\hline Custo/ave (US\$) & 1,214 & 1,123 & 1,007 & 1,201 & 1,150 & 1,052 \\
\hline Receita/ave (US\$) & 1,222 & 1,208 & 1,161 & 2,279 & 2,292 & 2,272 \\
\hline Lucro/ave (US\$) & 0,008 & 0,085 & 0,154 & 1,078 & 1,142 & 1,220 \\
\hline
\end{tabular}

${ }^{(1)}$ Com base na planilha de custos da Associação Paulista de Avicultura (APA) de abril de 2002. (2)Cotações de milho e farelo de soja baseadas no Avisite em abril de 2002. (3)Desinfecção, vacinas e medicamentos, energia elétrica, gás para aquecimento, mão-de-obra e encargos, encargos sociais sobre a produção, manutenção e reparos (APA, abril de 2002). ${ }^{(4)}$ Estimativa com base no preço do quilograma de frango vivo convencional, quilograma de frango resfriado convencional e quilograma de frango resfriado alternativo, em abril de 2002.

30\% e 60\% de silagem de grãos úmidos de milho, em substituição aos grãos de milho secos, respectivamente (Tabela 5). Este resultado está de acordo com dados levantados por Butolo (1999), que relatou que, apesar dos resultados de desempenho e rendimento de carcaça serem inferiores e, as aves criadas em sistema alternativo serem abatidas mais tardiamente, em relação à produção de frangos de corte convencional, o mercado é bastante promissor e remunera mais pelo produto diferenciado, em torno de US\$ 0,375 por quilograma de peso vivo, compensando os menores índices zootécnicos.

Dentro dos sistemas de criação, o retorno econômico foi maior, à medida que se incluiu silagem de grãos úmidos de milho, com maior lucro, por ave, de US\$ 0,077 e US\$ 0,146 no sistema de criação convencional e de US\$ 0,064 e US\$ 0,142 no sistema alternativo, quando da inclusão de 30\% e 60\% de silagem de grãos úmidos de milho, em substituição aos grãos secos, respectivamente (Tabela 5).

\section{Conclusões}

1. A silagem de grãos úmidos de milho pode substituir em até $60 \%$ o milho seco, nas rações para frangos de corte, sem prejudicar o desempenho, o rendimento de carcaça e os cortes, tanto no sistema de criação convencional quanto no alternativo, com melhora nos índices econômicos.
2. O sistema de criação alternativo propicia menor desempenho das aves, independentemente do nível de inclusão de silagem de grãos úmidos de milho, nas rações de frangos de corte, porém ocasiona um maior retorno econômico.

\section{Agradecimentos}

À Fundação de Amparo à Pesquisa do Estado de São Paulo (Fapesp), pelo financiamento do projeto que resultou neste trabalho.

\section{Referências}

ANDRADE, R.C.; SARTORI, J.R.; MARTINEZ, K.L.A.; COSTA, C.; PEZZATO, A.C.; OLIVEIRA, H.N. Silagem de grãos úmidos de milho e simbiótico na alimentação de frangos de corte criados nos sistemas convencional e alternativo. Revista Brasileira de Ciência Avícola, v.4, p.26, 2002. (Suplemento, 4).

APA. Associação Paulista de Avicultura. [Estatística: apuração do custo quilo do frango vivo na granja]. Disponível em: < http:// www.apa.com.br/framesta.htm>. Acesso em: abr. 2002.

BERTO, D.A.; LOPES, A.B.R.C.; COSTA, C. Silagem de grãos úmidos para suínos. In: SIMPÓSIO SOBRE MANEJO E NUTRIÇÃO DE AVES E SUÍNOS E TECNOLOGIA DA PRODUÇÃO DE RAÇÕES, 1., 2001, Campinas. Anais. Campinas: CBNA, 2001. p.203-213.

BUTOLO, J.E. Uso de aditivos na alimentação de aves: frangos de corte. In: SIMPÓSIO SOBRE AS IMPLICAÇÕES SOCIOECONÔMICAS DO USO DE ADITIVOS NA PRODUÇÃO ANIMAL, 1999, Piracicaba. Anais. Piracicaba: CBNA, 1999. p.85-94. 
CARRIJO, A.S.; MERLOTO, H.K.; AMARAL, A.N.; PEZZATO, A.C.; SARTORI, J.R.; MARTINS, C.L.; COSTA, C. Silagem de grãos de milho na alimentação de frangos de corte: desempenho e rendimento de carcaça. Revista Brasileira de Ciência Avícola, v.2, p.50, 2000. (Suplemento, 2).

COSTA, C.; ARRIGONI, M.B.; SILVEIRA, A.C.; CHARDULO, L.A.L. Silagem de grãos úmidos. In: SIMPÓSIO SOBRE NUTRIÇÃO DE BOVINOS, 7., 1999, Piracicaba. Anais. Piracicaba: Fealq, 1999. p.69-87.

DANNER, H.; MADZINGAIDZO, L.; HOLZER, M.; MAYRHUBER, L.; BRAUM, R. Extraction and purification of lactic acid from silages. Bioresource Technology, v.75, p.181-187, 2000.

DEMATTÊ FILHO, L.C.; MENDES, C.M.I. Viabilidade técnica e econômica na criação alternativa de frangos. In: CONFERÊNCIA APINCO DE CIÊNCIA E TECNOLOGIA AVÍCOLAS, 2., 2001, Campinas. Anais. Campinas: Facta, 2001. p.255-266.

GARCIA, D.C.; MAIER, J.C.; ELIAS, M.C. Desempenho de pintos alimentados com grãos de sorgo úmidos tratados com ácidos orgânicos. Revista Brasileira de Zootecnia, v.24, p.62-69, 1995.

GONÇALVES, J.C.; ANDRADE, R.C.; SARTORI, J.R.; MARTINEZ, K.L.A.; PEZZATO, A.C.; COSTA, C. Rendimento de carcaça e partes de frangos de corte alimentados com silagem de grãos úmidos de milho e simbiótico. Revista Brasileira de Ciência Avícola, v.4, p.27, 2002. (Suplemento, 4).

JORGE NETO, G.; DARI, R.L. Produtos químicos alternativos para promotores de crescimento. In: CONFERÊNCIA APINCO DE CIÊNCIA E TECNOLOGIA AVÍCOLAS, 2000, Campinas. Anais. Campinas: Facta, 2000. p.217-239.

LIMA, G.J.M.M. Milho e subprodutos na alimentação animal. In: SIMPÓSIO SOBRE INGREDIENTES NA ALIMENTAÇÃO ANIMAL, 1., 2001, Campinas. Anais. Campinas: CBNA, 2001. p.13-32.

LOPES, A.B.R.C. Silagem de grãos úmidos de milho em rações de suínos nas fases inicial, de crescimento e de terminação. 2000. 46p. Dissertação (Mestrado) - Universidade Estadual Paulista, Botucatu.

MAHANNA, B. Proper management assures high-quality silage grains. Feedstuffs, v.10, p.12-56, 1994.

MAIORKA, A. Adaptações digestivas pós-eclosão. In: CONFERÊNCIA APINCO DE CIÊNCIA E TECNOLOGIA
AVÍCOLAS, 2001, Campinas. Anais. Campinas: Facta, 2001. p.141152.

MARTINS, C.L.; CRUZ, V.C.; PINHEIRO, D.F.; SARTORI, J.R.; PEZZATO, A.C.; CARRIJO, A.S.; SILVA, M.D.P. Silagem de grãos úmidos de milho na alimentação de frangos de corte: peso de órgãos e morfometria intestinal. Revista Brasileira de Ciência Avícola, v.2, p.49, 2000. (Suplemento, 2).

MOLNÁR-PERL, I. Role of chromatography in the analysis of sugars, carboxylic acids and amino acids in food. Journal of Chromatography A. v.891, p.1-32, 2000.

NUMMER FILHO, I. Silagem de grão úmido de milho. In: SEMINÁRIO NACIONAL DE DESENVOLVIMENTO DA SUINOCULTURA, 9., 2001, Gramado. Anais. Gramado: ABCS, 2001. p.28-42.

ROSTAGNO, H.S.; ALBINO, L.F.T.; DONZELE, J.L.; GOMES, P.C.; FERREIRA, A.S.; OLIVEIRA, R.F.; LOPES, D.C. Tabelas brasileiras para aves e suínos: composição de alimentos e exigências nutricionais. Viçosa: Ed. da UFV, 2000. 141p.

SAMANTA, M.; BISWAS, P. Influence of lactobacillus culture, lactic acid and acetic acid on the performance of broilers. Indian Journal of Animal Health, v.34, p.137-140, 1995.

SARTORI, J.R.; COSTA, C.; PEZZATO, A.C.; MARTINS, C.L.; CARRIJO, A.S.; CRUZ, V.C.; PINHEIRO, D.F. Silagem de grãos úmidos de milho na alimentação de frangos de corte. Pesquisa Agropecuária Brasileira, v.37, p.1009-1015, 2002.

SAS INSTITUTE (Cary, Estados Unidos). SAS/STAT: user's guide. Version 6.11. $4^{\text {th }}$ ed. Cary, 1996. 842p.

SUPELCO BULLETIN. Analyzing fatty acids by packed column gas chromatography. Philadelphia: Sigma-Aldrich, 1998. 12p.

VALE, M.M. Desempenho de frangos de corte alimentados com níveis crescentes da mistura dos ácidos orgânicos fórmico e propiônico (70\%:30\%). 1998. 52p. Dissertação (Mestrado) - Escola Superior de Agricultura Luiz de Queiroz, Piracicaba.

WALDROUP, A.; KANIAWATI, S.; MAUROMOUSTAKOS, A. Performance characteristics and microbiological aspects of broiler fed diets supplemented with organic acids. Journal of Food Protection, v.58, p.482-489, 1995.

WILSON, R.K. A rapid accurate method for measuring volatile fatty acids and lactic acid in silage. Ruakura: Animal Research Institute, 1971. 12p.

Recebido em 24 de maio de 2004 e aprovado em 11 de abril de 2005 